\title{
APPLICATION OF OAT, WHEAT AND RYE BRAN TO MODIFY NUTRITIONAL PROPERTIES, PHYSICAL AND SENSORY CHARACTERISTICS OF EXTRUDED CORN SNACKS
}

\author{
Agnieszka Makowska ${ }^{1 凶}$, Anna Polcyn ${ }^{1}$, Sylwia Chudy ${ }^{2}$, Jan Michniewicz ${ }^{1}$ \\ ${ }^{1}$ Institute of Food Technology of Plant Origin, Poznań University of Life Sciences \\ Wojska Polskiego 31, 60-624 Poznań, Poland \\ ${ }^{2}$ Department of Dairy Technology, Poznań University of Life Sciences \\ Wojska Polskiego 31, 60-624 Poznań, Poland
}

\begin{abstract}
Background. Cereal products constitute the basis of the diet pyramid. While the consumption of such products as bread decreases, the group of food which popularity increase is cereal snacks. Unfortunately, the dietary value of this group of foodstuffs is limited. Thus, different types of cereal bran may be added to the produced snacks to enhance their nutritive value. However, an addition of bran may have an adverse effect on quality attributes of products.

Material and methods. Corn grits enriched with 20 and $40 \%$ oat, wheat and rye bran was extruded. Basic parameters determining the nutritive value, physical characteristics and sensory attributes of the six produced types of extrudates were measured and compared. Moreover, the effect of additives applied on viscosity of aqueous suspensions of the raw materials and extrudates under controlled conditions was measured using RVA.

Results. The dietary value of snacks containing bran depends on the type and quantitative shares of the additives. The content of dietary fibre in produced extrudates ranged from 6.5 to $15.8 \%$, including soluble dietary fibre at 2.1 to $3.7 \%$. With an increase of bran content in extrudates, their expansion decreased, density increased and the colour of extrudates changed (reduced brightness, increased $a^{*}$, decreased $b^{*}$ ). In sensory evaluation the highest acceptability was given to extrudates with a $20 \%$ addition of oat bran, while the lowest was given for those with $40 \%$ wheat bran. Based on PCA results positive correlations were found between overall desirability and crispiness, porosity, taste, colour and expansion. Negative correlations between desirability and hardness and density of extrudates were observed. The additives and their level also had an effect on changes in viscosity of aqueous suspensions measured using RVA. However, no correlation was found between quality features of extrudates and values of attributes measured in the analysis of viscosity.

Conclusion. In the production of corn extruded snacks an addition of oat, wheat and rye bran may be applied up to $20 \%$. Such products have adequate sensory and dietary quality. The Critical Paste Test (Whalen et al., 1996) is not applicable in the evaluation of suitability of the corn raw material with an addition of oat, wheat and rye bran to produce extrudates.
\end{abstract}

Key words: extrusion, bran, dietary fibre, critical paste test, quality

\footnotetext{
『agmak@up.poznan.pl 


\section{INTRODUCTION}

In view of changes in lifestyle, the growing prevalence of civilisation-related diseases and increased consumer awareness it is necessary to focus on food as a source of not only basic nutrients, but also other components having a beneficial effect on our health and well-being. Plant-origin products, including cereals, are primary sources of dietary fibre in our diet. However, it should be taken into account that not only the amount of consumed total dietary fibre but its fractional composition is important (Górecka et al., 2011). From the physiological point of view the soluble fractions of fibre have a highly advantageous effect in the prevention of civilisation-related diseases such as e.g. obesity, hypercholesterolemia, heart disease or diabetes. The soluble fractions of fibre exhibit a higher antioxidant activity than the insoluble ones (Esposito et al., 2005). It also has a greater gelation capacity and shows emulsifying properties (Sozer et al., 2014; Feng et al., 2013). The amount and fractional composition of dietary fibre found in cereals depend on the species. Wheat contains approx. $11-15 \%$ of dietary fibre (Boros, 2011), of which insoluble dietary fibre accounts for approx. 9-11\%. Markedly greater amounts of dietary fibre, mainly arabinoxylans, are found in rye. Including fructans, rye contains as much as $22 \%$ of dietary fibre ( $1 / 5$ as the soluble fraction) (Rakha et al., 2010). Oat is also a rich source of dietary fibre (Piątkowska et al., 2010). It may contain from 14 to $17 \%$ of dietary fibre. In this case the main fraction is composed of $\beta$-glucans. The content of $\beta$-glucans ranges from 4 to $7 \%$ in hulled oat and from 6 to $9 \%$ in bran (Gibiński, 2008). Dietary fibre, as well as numerous bioactive compounds, is distributed mainly in the outer fragments of kernels. They are removed in the form of bran during milling to produce white flour, most commonly used in baking.

Unfortunately, the level of consumption of wholemeal cereal products in Poland is relatively low. While in Germany as much as $20 \%$ of consumed bread is wholemeal bread, in Poland it accounts for only 4\% (Goryńska-Goldman, 2010). Moreover, in Poland the level of bread consumption has been decreasing systematically (Rocznik..., 2013). Within the last 20 years this drop is estimated at over 20\% (Goryńska-Goldman, 2010). Snacks constitute one of the few groups of cereal products, which consumption is increasing (Wesołowska, 2013). The basic materials for their production are corn or rice milling products (Rytel et al., 2012). Their dietary value is relatively low. These products supply high amount of saccharides, a slight amount of low-quality protein and little amount of dietary fibre. In order to increase the content of dietary fibre and accompanying bioactive substances in snacks, the traditional raw materials may be enriched with cereal bran, which not only improves the dietary value of the product, but also influences physical characteristics and sensory attributes of extrudates.

The aim of this study was to determine the effect of commercially available oat, wheat and rye bran on the nutritive value, physical properties and sensory attributes of corn snacks produced with their addition. Moreover, this study also determined the effect of applied additives on changes in dynamic viscosity of aqueous suspensions of materials and extrudates, recorded under controlled conditions.

\section{MATERIAL AND METHODS}

Material for analyses comprised corn grits, obtained from The Stanisław Grygier Mill (Wonieść, Poland) with granulation of $850-1250 \mu \mathrm{m}$, and commercially available bran: oat $(\mathrm{OB})$, wheat $(\mathrm{WB})$ and rye $(\mathrm{RB})$, purchased in Kupiec Company (Paprotnia, Poland). Bran prior to its addition to corn grits was comminuted in a WZ-1 laboratory mill (Sadkiewicz Instruments, Bydgoszcz, Poland) and sieved at mesh size of $650 \mu \mathrm{m}$.

Mixtures of corn grits and bran were extruded. On the basis of our earlier experiments the share of bran in the mixtures was 20 and $40 \%$. Extrusion was performed in an S-45 single-screw extruder (Metalchem, Gliwice, Poland) of L:D = 12:1 and compression rate of $3: 1$. The following process conditions were applied: temperature: section I/section II/head $135^{\circ} \mathrm{C} / 175^{\circ} \mathrm{C} / 135^{\circ} \mathrm{C}$; nozzle diameter 3.0 ; screw rotations $90 \mathrm{rpm}$. Mixtures of materials were supplemented with water to $15 \%$ at $24 \mathrm{~h}$ before extrusion.

\section{Chemical composition of extrudates}

The basic chemical composition of extrudates was determined. The content of protein was determined according to Kjeldahl (AACC, Method 46-06), fat content was assayed according to Soxhlet (AACC, 
Method 30-10); the ash content (AACC Method 08$-01)$ as well as the content of dietary fibre (total - TDF; soluble - SDF and insoluble - IDF) were determined according to Asp et al. (1983). The content of starch was calculated from the following formula:

Starch content $(\%$ d.m. $)=100-($ protein $(\%$ d.m. $)+$ ash (\% d.m.) + TDF (\% d.m.) + fat (\% d.m.))

\section{Physical properties of extrudates}

The expansion ratio (ER) was defined as a ratio of extrudate diameter to the diameter of the nozzle (Thymi et al., 2005). Bulk density of extrudates was expressed as a ratio of extrudate weight to its volume (Ali et al., 1996). Water Absorption Index (WAI) as well as Water Solubility Index (WSI) were determined following the method proposed by Anderson et al. (1969).

The colour of extrudates was measured using a Chroma Meter CR-410 reflectance colorimeter (Konica Minolta, Japan Sensing Inc.) in the CIE L*a*b* colour system, where L (0-100) defines brightness; a redness (a positive value) or the greenness (a negative value), $b$ - yellowness (a positive value) or blueness (a negative value) (Anton et al., 2009). The following measurement conditions were applied: Illumination wide-area illumination $/ 0^{\circ}$, illuminant condition - C and observer condition $2^{\circ}$ standard observer.

\section{Sensory analysis}

Snacks were subjected to sensory evaluation. A trained 10-member panel (in three sessions) evaluated porosity, crispiness, colour, taste as well as overall desirability of products. A 9-point hedonic scale was applied (1 - disliked extremely, 5 - neither liked nor disliked, 9 - liked extremely) (Meilgaard et al., 1999). The products were considered acceptable when $50 \%$ of the panellists gave them a score greater than or equal to 5 (liked slightly) (Conti-Silva et al., 2011).

\section{Analysis of the viscosity profile of materials used in the experiment}

Viscosity profile of aqueous suspensions of raw materials blends ( $10 \%$ d.m. $)$ was assessed in a RVA Tec Master apparatus (Perten Instruments, Hägersten, Sweden), in accordance with the standard AACC Method 76-21. Gelatinization temperature, peak viscosity, trough, breakdown, final viscosity and setback were determined.
The critical paste test (the viscosity profile measured at the gelatinization temperature of starch contained in the materials) of raw material blends was carried out according to Whalen (1998). Pasting temperature was determined in the standard AACC Method 76-21.

\section{Analysis of the viscosity profile of extrudates}

Viscosity profiles of extrudate solutions (10\% d.m.) were determined according to Whalen (1996). Cold viscosity, hot viscosity and final viscosity were determined.

\section{Statistical analysis}

The experiment was conducted in three replications. Results were analysed statistically using the Statistica 10 software. One-way analysis of variance was applied. Significance of differences was verified based on Tukey's test at the significance $\alpha=0.05$. The expansion ratio and density of extrudates were measured in 20 replications, WSI and WAI in six replications, while the other analyses were performed in triplicate.

The Principal Component Analysis (PCA) was conducted using the obtained data. All the data recorded in the tests was used to form the axes. The result is presented in a two-dimensional system (biplot) obtained by plotting the observations and variables on the plane formed by the calculated principal components. Additionally, the correlation matrix was constructed for the variables used in PCA.

\section{RESULTS AND DISCUSSION}

Produced extrudates differed in their chemical composition (Table 1). An increase in bran content in products from 20 to $40 \%$ resulted in an increased content of protein, fat, ash as well as dietary fibre. Also the type of added bran influenced the results.

Snacks with an addition of oat bran were characterized by the highest content of protein and fat, while the content of minerals was lowest. Significantly lower contents of TDF in snacks enriched with oat bran were recorded in comparison to snacks with an addition of wheat and rye bran. However, it should be stressed here that the snacks with oat bran addition contained relatively high amount of the SDF. According to Jenkins et al. (2000) the share of SDF in TDF should be 
Makowska, A., Polcyn, A., Chudy, S., Michniewicz, J. (2015). Application of oat, wheat and rye bran to modify nutritional properties, physical and sensory characteristics of extruded corn snacks. Acta Sci. Pol. Technol. Aliment., 14(4), 375-386. DOI: 10.17306/J. AFS.2015.4.37

Table 1. Comparison of chemical composition of extrudates with an addition of oat, wheat and rye bran

\begin{tabular}{|c|c|c|c|c|c|c|c|c|}
\hline \multirow{2}{*}{ Bran } & \multirow{2}{*}{$\begin{array}{c}\text { Bran } \\
\text { content } \\
\%\end{array}$} & Protein & Starch & Fat & Ash & TDF & IDF & SDF \\
\hline & & \multicolumn{7}{|c|}{$\%$ d.m. } \\
\hline \multirow[t]{2}{*}{ Oat } & 20 & $9.70^{\mathrm{b}}$ & 79.09 & $1.94^{\mathrm{b}}$ & $2.80^{\mathrm{a}}$ & 6.47 & $4.39^{\mathrm{a}}$ & $2.08^{\mathrm{a}}$ \\
\hline & 40 & $11.48^{\mathrm{e}}$ & 73.60 & $3.06^{\mathrm{d}}$ & $2.87^{\mathrm{a}}$ & 9.00 & $6.15^{\mathrm{b}}$ & $2.85^{\mathrm{c}}$ \\
\hline \multirow[t]{2}{*}{ Wheat } & 20 & $9.49^{b}$ & 75.90 & $1.64^{\mathrm{a}}$ & $3.13^{\mathrm{b}}$ & 9.84 & $7.78^{c}$ & $2.06^{\mathrm{a}}$ \\
\hline & 40 & $11.08^{\mathrm{d}}$ & 67.21 & $2.46^{c}$ & $3.52^{\mathrm{c}}$ & 15.72 & $12.92^{\mathrm{e}}$ & $2.81^{\mathrm{c}}$ \\
\hline \multirow[t]{2}{*}{ Rye } & 20 & $9.17^{\mathrm{a}}$ & 77.18 & $1.53^{\mathrm{a}}$ & $3.07^{\mathrm{b}}$ & 9.04 & $6.54^{\mathrm{b}}$ & $2.50^{\mathrm{bc}}$ \\
\hline & 40 & $10.43^{c}$ & 69.77 & $2.25^{\mathrm{c}}$ & $3.41^{\mathrm{c}}$ & 14.14 & $10.44^{\mathrm{d}}$ & $3.70^{\mathrm{d}}$ \\
\hline
\end{tabular}

Different letters in the superscript in the same column indicate significant differences between values at the significance level of $\alpha=0.05$.

approx. 30\%. In the snacks with an addition of 20 and $40 \%$ of oat bran SDF accounted for approx. $32 \%$ of TDF. In extrudates with an addition of rye bran the content of this fraction was $26-28 \%$, while in snacks with an addition of wheat bran the share of SDF in relation to the TDF was the least advantageous and amounted to $18-21 \%$. Observed differences result from the different chemical composition of added bran. From the point of view of SDF to IDF ratio the most advantageous dietary value was found for snacks with an addition of oat bran, followed by rye, while the lowest was that of snacks with an addition of wheat bran. However, all these products still contain minimum of $6 \mathrm{~g}$ dietary fibre in $100 \mathrm{~g}$ product, so in accordance with the binding regulations they may be classified as foodstuffs with a high content of dietary fibre (EFSA, 2007).

The used additives affected also physical characteristics of extrudates. With an increase in the addition of bran the expansion rate decreased and density of extrudates increased (Table 2).

Expansion of extrudates substantially determines quality of extrudates. The highest expansion ratio (ER) was found for snacks with $20 \%$ addition of oat bran, while it was lowest at $40 \%$ addition of wheat bran. An increase in the content of oat and wheat bran from

Table 2. Effect of bran addition on physical characteristics of extrudates

\begin{tabular}{lccccc}
\hline Bran & $\begin{array}{c}\text { Bran } \\
\text { content } \\
\%\end{array}$ & ER & $\begin{array}{c}\text { Density } \\
\mathrm{g} \cdot \mathrm{cm}^{-3}\end{array}$ & $\begin{array}{c}\text { WAI } \\
\mathrm{g} \cdot \mathrm{g}^{-1}\end{array}$ & $\begin{array}{c}\text { WSI } \\
\%\end{array}$ \\
\hline Oat & 20 & $4.61^{\mathrm{e}}$ & $0.009^{\mathrm{a}}$ & $600^{\mathrm{bc}}$ & $26.91^{\mathrm{c}}$ \\
& 40 & $3.22^{\mathrm{c}}$ & $0.017^{\mathrm{b}}$ & $555^{\mathrm{a}}$ & $24.81^{\mathrm{bc}}$ \\
Wheat & 20 & $3.58^{\mathrm{d}}$ & $0.020^{\mathrm{c}}$ & $607^{\mathrm{c}}$ & $23.63^{\mathrm{b}}$ \\
& 40 & $2.55^{\mathrm{a}}$ & $0.026^{\mathrm{d}}$ & $582^{\mathrm{b}}$ & $16.41^{\mathrm{a}}$ \\
Rye & 20 & $3.13^{\mathrm{bc}}$ & $0.018^{\mathrm{b}}$ & $589^{\mathrm{b}}$ & $29.06^{\mathrm{d}}$ \\
& 40 & $3.01^{\mathrm{b}}$ & $0.021^{\mathrm{c}}$ & $563^{\mathrm{ab}}$ & $25.11^{\mathrm{c}}$ \\
\hline
\end{tabular}

Different letters in the superscript in the same column indicate significant differences between values at the significance level of $\alpha=0.05$. 
20 to $40 \%$ resulted in a reduction of expansion by approx. $30 \%$. A lesser decrease was recorded in products with an addition of rye bran. Density of extruded products was inversely correlated with the ER value. An increased addition of bran resulted in an increased density of the product. When comparing bulk density of extrudates it was shown that an addition of wheat bran had the greatest negative effect on the value of this parameter. The lowest value was recorded when oat bran was added. The differences in ER and density values of extrudates produced with addition of bran were dependent on the type of bran and amounted to $89 \%, 30 \%$ and $16 \%$, for oat, wheat and rye bran, respectively (Table 2).

The expansion and density of extruded products depend to a considerable degree on the chemical composition of raw materials. A high content of dietary fibre, particularly its insoluble fraction, and a relatively low content of starch cause a lower expansion of extrudates at their simultaneous density (Robin et al., 2011).

Produced extrudates differed also in terms of WAI and WSI values. Higher values of WAI (by approx. $5-9 \%$ ) were obtained at the $20 \%$ rather than $40 \%$ addition of bran. When comparing the effect of addition of different bran types, the highest WAI value was found for products containing wheat bran. Oat and rye bran contain more of the SDF, which is dissolved during analysis and increases amount of soluble substances (WSI).

With an increase in bran content from 20 to $40 \%$ WSI values decreased (Table 2). The decrease was about $8 \%$ in the case of the increasing share of oat bran, and $13 \%$ for rye bran. It reached up to $30 \%$, when the wheat bran content in extrudates increased. Similar trends were recorded by Rzedzicki et al. (2004) as well as Sobota and Rzedzicki (2004) when investigating WSI of extrudates in the variable function for the content of other high-fibre materials. The lowest WSI values were found for extrudates with the wheat bran addition. On the basis of chemical composition of extrudates it can be stated that wheat bran contained the highest amount of dietary fibre (mainly IDF), as well as the lowest amount of starch, from which soluble substances are formed as a result of dextrinization (Smith, 1992). Another factor determining WSI values is the intensity of shear forces. The fat reduces shear forces acting in the extruder chamber. Probably that is why in the extrudates with the addition of oat bran (which contained higher amount of fat) in comparison to extrudates with the rye bran addition had lower WSI values, although they contained higher amount of starch.

The type of added bran and its amount also influenced the colour of extrudates (Table 3). The highest brightness value was recorded for extrudates with a $20 \%$ addition of oat bran, while the lowest was obtained for a $40 \%$ addition of wheat bran. Snacks with an addition of $40 \%$ of wheat bran were characterized by the highest redness (a* value) and the lowest yellowness ( $b^{*}$ value). The increasing amount of added oat and wheat bran caused considerable changes in the colour of snacks, while these differences were significantly smaller in snacks with an addition of rye bran.

Table 3. Effect of bran addition on colour determinant of extrudates

\begin{tabular}{lcccc}
\hline Bran & $\begin{array}{c}\text { Bran } \\
\text { content } \\
\%\end{array}$ & $\mathrm{~L}^{*}$ & $\mathrm{a}^{*}$ & $\mathrm{~b}^{*}$ \\
\hline Oat & 20 & $84.80^{\mathrm{e}}$ & $-0.9^{\mathrm{a}}$ & $37.84^{\mathrm{e}}$ \\
& 40 & $74.75^{\mathrm{c}}$ & $1.87^{\mathrm{c}}$ & $29.68^{\mathrm{c}}$ \\
Wheat & 20 & $76.20^{\mathrm{d}}$ & $1.03^{\mathrm{b}}$ & $34.28^{\mathrm{d}}$ \\
& 40 & $65.42^{\mathrm{a}}$ & $4.83^{\mathrm{f}}$ & $25.26^{\mathrm{a}}$ \\
Rye & 20 & $73.29^{\mathrm{b}}$ & $2.32^{\mathrm{d}}$ & $29.32^{\mathrm{c}}$ \\
& 40 & $74.31^{\mathrm{c}}$ & $2.52^{\mathrm{e}}$ & $27.27^{\mathrm{b}}$ \\
\hline
\end{tabular}

Different letters in the superscript in the same column indicate significant differences between values at the significance level of $\alpha=0.05$.

In the next stage of this experiment snacks were subjected to sensory examination (Table 4). The highest desirability for all the investigated attributes were recorded for snacks with a $20 \%$ addition of oat bran. Lower acceptability were given to products with a $40 \%$ addition of oat bran as well as $20 \%$ rye and wheat bran. In turn, a $40 \%$ addition of wheat and rye bran caused a considerable deterioration of sensory quality of snacks. These extrudates were no acceptable 
Makowska, A., Polcyn, A., Chudy, S., Michniewicz, J. (2015). Application of oat, wheat and rye bran to modify nutritional properties, physical and sensory characteristics of extruded corn snacks. Acta Sci. Pol. Technol. Aliment., 14(4), 375-386. DOI: 10.17306/J. AFS.2015.4.37

Table 4. Effect of bran addition on sensory evaluation of extrudates

\begin{tabular}{lcccccc}
\hline Bran & $\begin{array}{c}\text { Bran } \\
\text { content } \\
\%\end{array}$ & Taste & Colour & Crispiness & Porosity & $\begin{array}{c}\text { Overall } \\
\text { desirability }\end{array}$ \\
\hline Oat & 20 & $7.3^{\mathrm{c}}$ & $7.9^{\mathrm{c}}$ & $7.8^{\mathrm{c}}$ & $8.2^{\mathrm{c}}$ & $7.3^{\mathrm{c}}$ \\
& 40 & $6.1^{\mathrm{b}}$ & $7.1^{\mathrm{c}}$ & $5.5^{\mathrm{b}}$ & $5.3^{\mathrm{b}}$ & $5.0^{\mathrm{b}}$ \\
Wheat & 20 & $5.7^{\mathrm{b}}$ & $4.6^{\mathrm{b}}$ & $5.5^{\mathrm{b}}$ & $5.5^{\mathrm{b}}$ & $4.6^{\mathrm{ab}}$ \\
& 40 & $3.0^{\mathrm{a}}$ & $2.8^{\mathrm{a}}$ & $2.6^{\mathrm{a}}$ & $2.6^{\mathrm{a}}$ & $2.8^{\mathrm{a}}$ \\
Rye & 20 & $5.5^{\mathrm{b}}$ & $3.7^{\mathrm{ab}}$ & $3.3^{\mathrm{a}}$ & $3.3^{\mathrm{a}}$ & $5.5^{\mathrm{b}}$ \\
& 40 & $2.9^{\mathrm{a}}$ & $2.8^{\mathrm{a}}$ & $2.5^{\mathrm{a}}$ & $2.8^{\mathrm{a}}$ & $3.0^{\mathrm{a}}$ \\
\hline
\end{tabular}

Different letters in the superscript in the same column indicate significant differences between values at the significance level of $\alpha=0.05$.

by panellist (scores of sensory evaluation of the snacks were below 5 points).

Physical characteristics and quality properties of extrudates are determined by the chemical composition and physical properties of raw materials. In order to show how each type and the amount of added bran may modify rheological properties of raw material pasting characteristic was analysed. This facilitates inference on viscosity raw material and its changes during extrusion, influencing the expansion of extrudates (Cauvain et al., 2005). Results of the analysis are given in Table 5.

Gelatinization temperature of raw materials suspensions ranged from 71.8 to $75.0^{\circ} \mathrm{C}$. At a higher addition of bran a lower gelatinization temperature was recorded. It was also shown that viscosity of raw material suspension with an addition of different bran types varied. The highest value was recorded when oat bran was added. This pertains both to peak viscosity, trough and final viscosity. Lower values (by approx. 50\%) were recorded in the case of mixtures containing wheat bran. When analysing samples with an addition of rye bran viscosity was several times lower. This is probably caused by the high activity of amylolytic enzymes, which break down amylose and amylopectin chains, thus reducing viscosity of suspensions (Poutanen, 1997).

The standard test of viscosity measurement does not provide an unambiguously assessment of

Table 5. Effect of bran addition on pasting characteristic of raw material blends (standard test AACC Method 76-21)

\begin{tabular}{lccccccc}
\hline Bran & $\begin{array}{c}\text { Bran content } \\
\%\end{array}$ & $\begin{array}{c}\text { Tp } \\
{ }^{\circ} \mathrm{C}\end{array}$ & $\begin{array}{c}\text { Peak viscosity } \\
\mathrm{cP}\end{array}$ & $\begin{array}{c}\text { Trough } \\
\mathrm{cP}\end{array}$ & $\begin{array}{c}\text { Break-down } \\
\mathrm{cP}\end{array}$ & $\begin{array}{c}\text { Final viscosity } \\
\mathrm{cP}\end{array}$ & $\begin{array}{c}\text { Setback } \\
\mathrm{cP}\end{array}$ \\
\hline Oat & 20 & $75.0^{\mathrm{c}}$ & $1173^{\mathrm{e}}$ & $1017^{\mathrm{e}}$ & $156^{\mathrm{c}}$ & $3254^{\mathrm{e}}$ & $2237^{\mathrm{e}}$ \\
& 40 & $72.4^{\mathrm{ab}}$ & $1525^{\mathrm{f}}$ & $1132^{\mathrm{e}}$ & $393^{\mathrm{d}}$ & $3286^{\mathrm{e}}$ & $2154^{\mathrm{e}}$ \\
Wheat & 20 & $75.0^{\mathrm{c}}$ & $873^{\mathrm{d}}$ & $750^{\mathrm{d}}$ & $123^{\mathrm{c}}$ & $2031^{\mathrm{d}}$ & $1281^{\mathrm{d}}$ \\
& 40 & $74.1^{\mathrm{bc}}$ & $571^{\mathrm{c}}$ & $504^{\mathrm{c}}$ & $67^{\mathrm{b}}$ & $1308^{\mathrm{c}}$ & $804^{\mathrm{c}}$ \\
\multirow{2}{*}{ Rye } & 20 & $73.3^{\mathrm{b}}$ & $232^{\mathrm{b}}$ & $192^{\mathrm{b}}$ & $40^{\mathrm{ab}}$ & $635^{\mathrm{b}}$ & $443^{\mathrm{b}}$ \\
& 40 & $71.8^{\mathrm{a}}$ & $113^{\mathrm{a}}$ & $97^{\mathrm{a}}$ & $16^{\mathrm{a}}$ & $306^{\mathrm{a}}$ & $209^{\mathrm{a}}$ \\
\hline
\end{tabular}

Different letters in the superscript in the same column indicate significant differences between values at the significance level of $\alpha=0.05$. 
suitability of the raw material for the production of good quality extrudates. Whalen (1998) proposed the application of critical paste test. In the case of corn as the material which viscosity grows intensively at the gelatinization temperature should be more suitable for the production of extruded snacks. In this study it was stated that the viscosity of the paste increased most rapidly with the addition of oat bran to corn grits. Lower viscosity values were reported when wheat bran was added. In turn, the lowest viscosity values were found for blends of corn grits and rye bran (the viscosity increased only slightly at the beginning of analyses and decreased afterwards; Fig. 1). Based on the results it may be concluded that the viscosity is influenced not only by the presence of starch, but also other components differing in their affinity to water, such as $\beta$-glucans (oat bran), arabinoxylanes (rye bran) as well as IDF (wheat bran) (Zhu et al., 2016; Kale et al., 2015; Fabek et al., 2014). Viscosity of the samples, particularly that containing rye bran, may also be influenced by the activity of amylolytic enzymes breaking down amylose and amylopectin chains. According to the theory proposed by Whalen (1998), corn grits with an addition of oat bran should be the most suitable raw material for snacks production, while corn grits with an addition of rye bran is an inferior material. In contrast to the raw material blends with an addition of oat bran, low viscosity values recorded for mixtures with a share of rye bran were not reflected in the results of quality assessment of snacks. Despite the considerably lower values of viscosity of the suspension, quality attributes of snacks with an addition of rye bran did not significantly diverge from those of the product containing wheat bran. Our results indicate that the criteria proposed by Whalen (1998) for the assessment of material suitability, satisfactory for corn, are not applicable in the prediction of quality of extruded products with a share of bran.

In Table 6 results of viscosity test of extrudates are presented. According to the theory cold viscosity value is an indicator of starch gelatinization during extrusion. Gelatinized starch swells and at low temperatures it is dispersed, so cold viscosity suspension is high. Residue of non-gelatinized starch swells

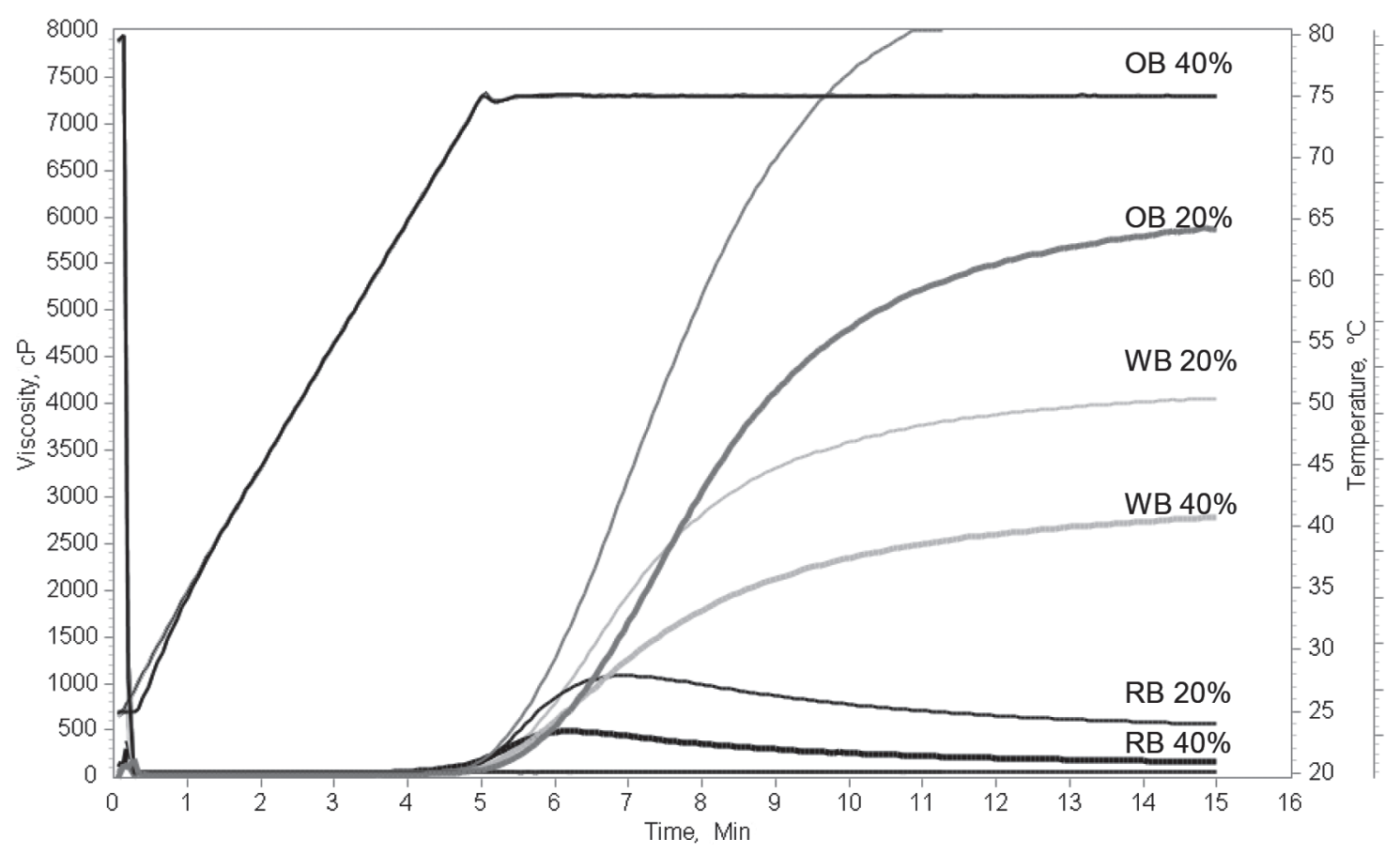

Fig. 1. Comparison of paste profiles of raw material blends according to Critical Paste Test: OB - oat bran, WB - wheat bran, RB - rye bran 
Makowska, A., Polcyn, A., Chudy, S., Michniewicz, J. (2015). Application of oat, wheat and rye bran to modify nutritional properties, physical and sensory characteristics of extruded corn snacks. Acta Sci. Pol. Technol. Aliment., 14(4), 375-386. DOI: 10.17306/J. AFS.2015.4.37

Table 6. Effect of bran addition on pasting properties of extrudates

\begin{tabular}{lcccc}
\hline Bran & $\begin{array}{c}\text { Bran content } \\
\%\end{array}$ & $\begin{array}{c}\text { Cold viscosity } \\
\mathrm{cP}\end{array}$ & $\begin{array}{c}\text { Hot viscosity } \\
\mathrm{cP}\end{array}$ & $\begin{array}{c}\text { Final viscosity } \\
c P\end{array}$ \\
\hline Oat & 20 & $448^{\mathrm{d}}$ & $463^{\mathrm{c}}$ & $520^{\mathrm{c}}$ \\
& 40 & $333^{\mathrm{bc}}$ & $309^{\mathrm{b}}$ & $278^{\mathrm{a}}$ \\
\multirow{2}{*}{ Wheat } & 20 & $297^{\mathrm{ab}}$ & $254^{\mathrm{a}}$ & $342^{\mathrm{b}}$ \\
& 40 & $364^{\mathrm{c}}$ & $297^{\mathrm{ab}}$ & $280^{\mathrm{a}}$ \\
Rye & 20 & $248^{\mathrm{a}}$ & $288^{\mathrm{ab}}$ & $316^{\mathrm{ab}}$ \\
& 40 & $291^{\mathrm{a}}$ & $302^{\mathrm{b}}$ & $324^{\mathrm{ab}}$ \\
\hline
\end{tabular}

Different letters in the superscript in the same rows indicate significant differences between values at the significance level of $\alpha=0.05$.

during heating, increasing gel viscosity and thus the peak of hot viscosity is plotted on the graph. However, it should be remembered that the value of cold viscosity depends also on the intensity of shear forces and a lower viscosity may sometimes result from the progressing dextrinization rather than a lower gelatinization rate (Whalen et al., 1996). Table 6 presents changes in viscosity of extrudates suspensions.

The highest value of cold viscosity was recorded for the suspension of extrudates containing $20 \%$ of oat bran, while it was the lowest for that containing rye bran. Analyses of extrudate with an addition of $20 \%$ of oat bran as well as 20 and $40 \%$ of rye bran showed a slight increase in viscosity at the initial stage of heating; however, no definite peak indicating the presence of non-gelatinized starch in extrudate was recorded for any sample. It was also shown that with an increase in the share of wheat and rye bran in samples the value of viscosity increased. An opposite trend was observed in the case of oat bran application. Viscosity (cold, hot and final values) of samples with a $40 \%$ addition of oat bran was lower than at a $20 \%$ addition. This may result from the presence of fat in oat bran, which may form complexes with starch, thus reducing its solubility. When comparing results of final viscosity higher values of this index were found for samples with $40 \%$ rather than $20 \%$ of bran contents when oat and wheat bran was added; in contrast, in the case of rye bran the results did not differ statistically irrespective of the amount added. In this experiment extrusion conditions were constant, thus the observed differences probably result from a different chemical composition and susceptibility to physical transformations of extruded blends.

In order to facilitate the interpretation of the influence of bran additives on extrudate features, PCA was performed. Two principal components were obtained, based on calculations, which allowed explaining $83.86 \%$ of the total variance of the variables analysed. The first and the second principal component carry $65.85 \%$ and $20.00 \%$ of information about the tested products represented by the variables, respectively. The relation between the data input and the principal components is plotted on the Figure 2.

Based on PCA a positive correlation was found between overall desirability, and crispiness, porosity, taste, colour as well as the expansion rate ER (vectors are found in the same part of the graph and angles between them are small). Hardness and density of extrudates were negatively correlated with overall desirability. Hardness and density were also negatively correlated with ER (the vectors are found at opposite parts of the graph). It was also shown that colour in sensory examination is positively correlated with brightness and yellowness of the sample, while it is inversely correlated with redness. In turn, there is no correlation between characteristics of extrudates and viscosity of suspension of the materials measured both under standard conditions and in the critical paste test. This confirms that the method proposed by Whalen (1998) for the selection of adequate quality of corn material for the production of extruded snacks does 


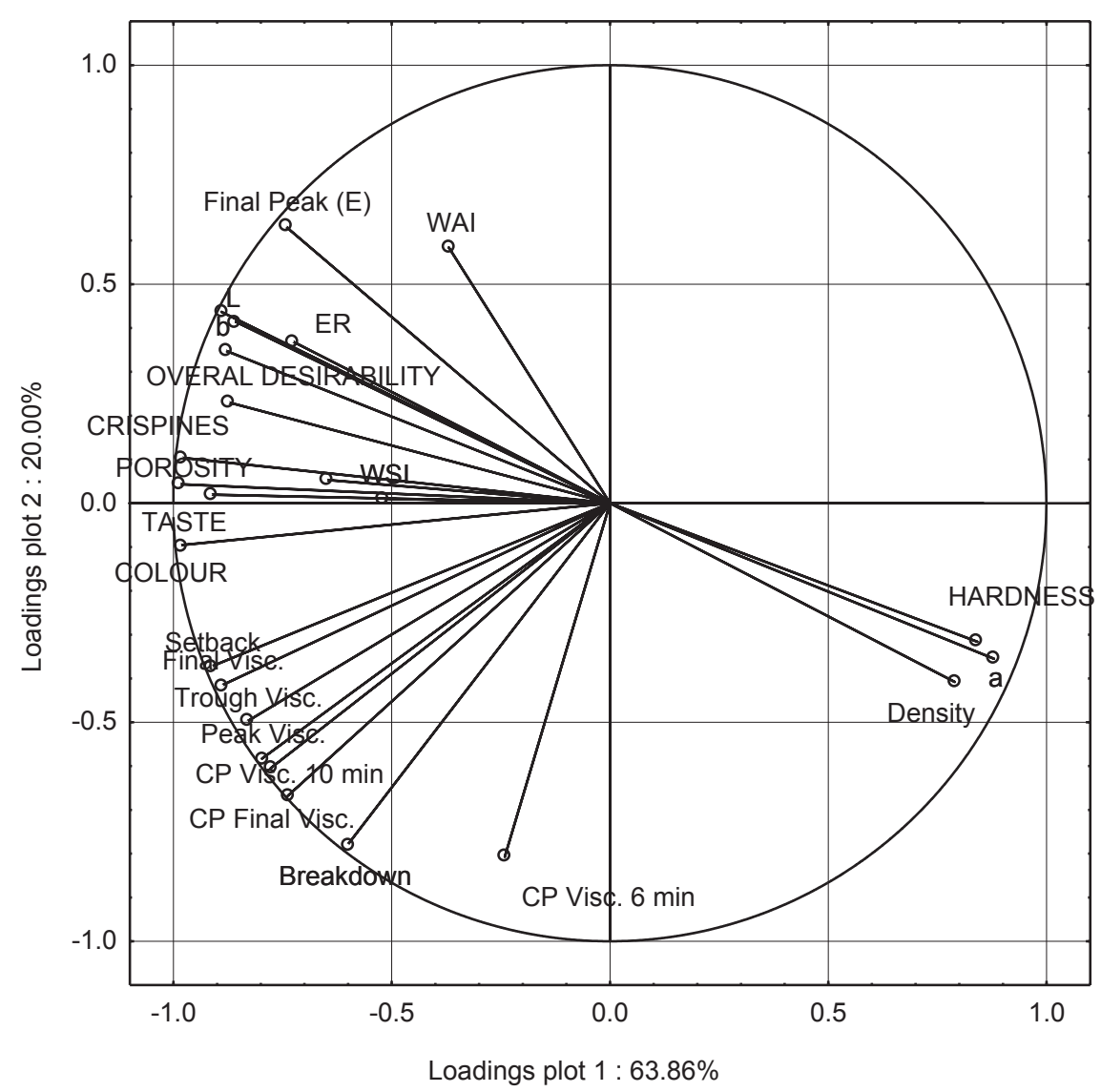

Fig. 2. Two-dimensional plot representing the PCA of loadings plot for samples of raw material and extrudates with bran additions

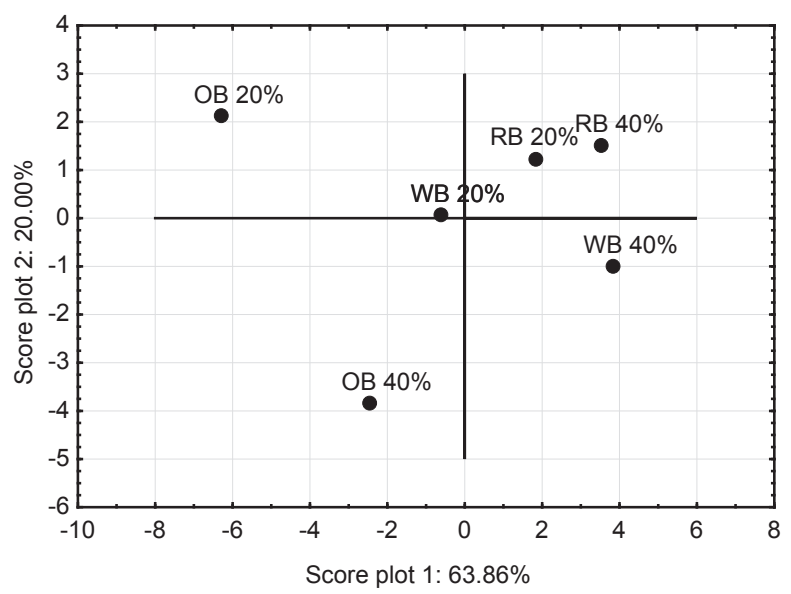

Fig. 3. Two-dimensional plot representing the PCA of score plot for samples of extrudates with bran additions not work when other additives are used, modifying viscosity over a wide range of values.

PCA makes it possible to cluster samples and infer on their similarity based on all analysed characteristics reduced to two principal components (Fig. 3). It was shown that samples with an addition of rye bran, irrespective of the added amounts, exhibited similar characteristics. Similar properties were also observed for the sample with a $20 \%$ addition of wheat bran. In turn, samples with an addition of oat bran were characterized by other properties. These properties changed greatly with an increase in the share of oat bran.

\section{CONCLUSIONS}

The addition of oat, wheat and rye bran modifies physical and dietary properties of produced extrudates. 
The application of a $20 \%$ of bran addition, irrespective of its type, makes it possible to classify these snacks as high-fibre products.

Among the tested samples extrudates with the addition of oat bran characterise by the highest expansion and the lowest density. An increase in bran content from 20 to $40 \%$ in extrudates reduces the expansion rate and increases product density, leading to a deterioration of product quality in sensory evaluation, confirmed by PCA. The type and amount of bran addition influences also the colour of extrudates. Snacks with an addition of oat bran characterise by the highest brightness and the most intensive yellow colour.

In terms of sensory attributes the best properties were found for snacks with a $20 \%$ addition of oat bran. The addition of rye and wheat bran at $20 \%$ and oat bran at $40 \%$ provides sufficient quality product, while the properties of snacks with an addition of $40 \%$ wheat and rye bran are not acceptable by panellists.

The type and amount of bran addition modify also physical properties of the extrudates. Based on the Critical Paste Test (performed with RVA) it was stated that aqueous suspensions of the raw material with an addition of oat bran exhibit greater viscosity that in the case of wheat and rye. Unfortunately, large differences in recorded viscosities show that the test may not be the basis for indication of a raw material for obtaining the best quality product. The Principal Component Analysis (PCA) shows a lack of correlation between quality of snacks and viscosity parameters of raw material suspensions.

\section{REFERENCES}

AACC. Approved Methods of the American Association of Cereal Chemists. 2000.

Ali, Y., Hanna, M. A., Chinnaswamy, R. (1996). Expansion characteristics of extruded corn grits. Lebensm-Wiss Technol., 29, 702-707.

Anderson, R. A., Conway, H. F., Pfeifer, V. F., Griffin, E. L. Jr. (1969). Gelatinization of corn grits by roll and extrusion cooking. Cereal Sci. Today, 14, 11-12.

Anton, A. A., Fulcher, R. G., Arntfield, S. D. (2009). Physical and nutritional impact of fortification of corn starchbased extruded snacks with common bean (Phaseolus vulgaris L.) flour: Effects of bean addition and extrusion cooking. Food Chem., 113, 989-996.
Asp, N. G., Johansson, C. G., Hallmer, H., Silijestrom, M. (1983). Rapid enzymatic assay of insoluble and soluble dietary fibre. J. Agric. Food Chem., 31, 476-482.

Boros, D. (2011). Zboża wysokiej jakości [Cereals of high quality]. AgroSerwis, 5, 57-66 [in Polish].

Cauvain, S. P., Young, L. S., Salmon, S. (2005). Using cereal science and technology for the benefit of consumers. In Proceedings of the 12th International ICC Cereal and Bread Congress. 24-26th May, 2004, Harrogate, UK (e-Book Google).

Conti-Silva, A. C., Machado Pinto e Silva, M. E., Gomes Arêas, J. A. (2011). Sensory acceptability of raw and extruded bovine rumen protein in processed meat products. Meat Sci., 88, 652-656.

EFSA (European Food Safety Authority). (2007). Statement of the scientific panel on dietetic products, nutrition and allergies on a request from the commission related to dietary fibre. Retrieved from http://www.icc.or.at/news/ EFSA_Panel_Statement_on_Dietary_Fibre.pdf.

Esposito, F., Arlotti, G., Bonifati, A. M., Napolitan, A., Vitale, D., Fogliano, V. (2005). Antioxidant activity and dietary fibre in durum wheat bran by-products. Food Res. Int., 38, 1167-1173.

Fabek, H., Messerschmidt, S., Brulport, V., Douglas Goff, H. D. (2014). The effect of in vitro digestive processes on the viscosity of dietary fibres and their influence on glucose diffusion. Food Hydrocoll., 35, 718-726.

Feng, B., Ma, L. J., Yao, J. J., Fang, Y., Mei, Y. A., Wei, S. M. (2013). Protective effect of oat bran extracts on human dermal fibroblast injury induced by hydrogen peroxide. J. Zhejiang Univ. Sci. B, 14, 97-105.

Górecka, D., Janus, P., Borysiak-Marzec, P., Dziedzic, K. (2011). Analiza spożycia błonnika pokarmowego i jego frakcji w Polsce w ostatnim dziesięcioleciu w oparciu o dane GUS [Analysis of consumption of dietary fiber and its fractions in Poland in the last decade based]. Probl. Hig. Epid., 92, 705-708 [in Polish].

Gibiński, M. (2008). B-glukany owsa jako składnik żywności funkcjonalnej [Oat's $\beta$-glucans as a functional food ingredient]. Żywn. Nauka Techn. Jakość, 2, 15-29 [in Polish].

Goryńska-Goldmann, E. (2010). Tendencje zmian w konsumpcji pieczywa $\mathrm{w}$ Polsce [Consumption trends of bread in Poland]. Acta Sci. Pol.. Oeconomia, 9, 73-86 [in Polish].

Jenkins, D. J. A., Kendall, C. W. C., Axelsen, M. A., Livia, S. A., Vuksan, V. (2000). Viscous and nonviscous fibres, nonabsorbable and low glycaemic index carbohydrates, blood lipids and coronary heart disease. Curr. Opin. Lipid., 11, 49-56. 
Kale, M. S., Yadav, M. P., Hicks, K. B., Hanah, K. (2015). Concentration and shear rate dependence of solution viscosity for arabinoxylans from different sources. Food Hydrocoll., 47, 178-183.

Meilgaard, M., Civille, G. V., Carr, B. T. (1999). Sensory evaluation techniques. Boca Raton: CRC Press.

Piątkowska, E., Witkowicz, R., Pisulewska, E. (2010). Podstawowy skład chemiczny wybranych odmian owsa siewnego [Basic chemical composition of selected cultivars of oats]. Żywn. Nauka Techn. Jakość, 3, 88-99 [in Polish].

Poutanen, K. (1997). Enzymes: An important tool in the improvement of the quality of cereal foods. Trends Food Sci. Techn., 8, 300-306.

Rakha, A., Åman, P., Andersson, R. (2010). Characterisation of dietary fibre components in rye products. Food Chem., 119, 859-867.

Robin, F., Dubois, C., Curti, D., Schuchmann, H. P., Palzer, S. (2011). Effect of wheat bran on the mechanical properties of extruded starchy foams. Food Res. Int., 44, 2880-2888.

Rzedzicki Z., Sobota A., Zarzycki P. (2004). Influence of pea hulls on the twin screw extrusion cooking process of cereal mixtures and the physical properties of extrudate. Int. Agrophys., 18, 73-81.

Rocznik Statystyczny Rolnictwa [Statistical Yearbook of Agriculture] 2013. Warszawa: GUS [in Polish].

Rytel, E., Tajner-Czopek, A., Pęksa, A., Kita, A., Miedzianka, J. (2012). Wpływ rodzaju dodatku i temperatury ekstruzji na zawartość akrylamidu w chrupkach kukurydzianych [The impact of the type of additive and extrusion temperature on the content of acrylamide in corn snacks]. Bromatol. Chem. Toksyk., 3, 315-319 [in Polish].
Smith, A. C. (1992). Studies on the physical structure of starch based material in the extrusion cooking process. In Food extrusion science and technology (p. 573-619). New York: M. Dekker.

Sobota, A., Rzedzicki, Z. (2004). Badania nad technologią ekstruzji dwuślimakowej ekstrudatów z udziałem otrąb pszennych [Research on twin-screw extrusion technology of extrudates with the participation of wheat bran]. Ann. Univ. Mariae Curie-Skłodowska. Sectio E, Agricultura, 59, 303-313 (in Polish).

Sozer, N., Cicerelli, L., Heiniö, R. L., Poutanen, K. (2014). Effect of wheat bran addition on in vitro starch digestibility, physico-mechanical and sensory properties of biscuits. J. Cereal Sci., 60, 105-113.

Thymi, S., Krokida, M. K., Pappa, A., Maroulis, Z. B. (2005). Structural properties of extruded corn starch. J. Food Eng., 68, 519-526.

Wesołowska, A. (2013). Polski rynek słonych przekąsek obecnie i w przyszłości [Polish salty snacks market now and in the future]. Przem. Spoż., 67, 36-37 [in Polish].

Whalen, P. J. (1998). Detection of differences in corn quality for extrusion process by Rapid Visco Analyser. Cereal Foods World, 43, 69-72.

Whalen, P. J., Bason, M. L., Booth, R. I. (1996). Measuring degree of cook in extruded foods using the Rapid Visco Analyser. In Y.A. Williams, C.W. Wrigley (Eds.), Proc. 45th Aust. Cereal Chem. Conf., Royal Aust. Chem. Inst, 289-293.

Zhu, F., Du, B., Xu, B. (2016). A critical review on production and industrial applications of beta-glucans. Food Hydrocoll., 52, 275-288.

\section{WYKORZYSTANIE OTRAB OWSIANYCH, PSZENNYCH I ŻYTNICH DO KSZTAŁTOWANIA WŁAŚCIWOŚCI DIETETYCZNYCH, CECH FIZYCZNYCH I SENSORYCZNYCH EKSTRUDOWANYCH PRZEKĄSEK KUKURYDZIANYCH}

\section{STRESZCZENIE}

Wstęp. Produkty zbożowe są podstawą piramidy żywieniowej. Przekąski są grupą produktów zbożowych, których popularność wciąż wzrasta. Niestety, niewielka jest wartość dietetyczna tego typu żywności. W celu jej zwiększenia do produkcji przekąsek można zastosować dodatek różnego rodzaju otrąb zbożowych. Domieszka otrąb może jednak oddziaływać niekorzystnie na cechy jakościowe produktów.

Materiat i metody. Kaszkę kukurydzianą z dodatkiem 20 i 40\% otrąb owsianych, pszennych i żytnich poddawano ekstruzji. Porównano podstawowe parametry określające wartość odżywczą oraz cechy fizyczne i sensoryczne uzyskanych sześciu rodzajów ekstrudatów. Określono także wpływ zastosowanych dodatków na lepkość wodnych zawiesin surowców i ekstrudatów mierzoną w kontrolowanych warunkach z zastosowaniem RVA. 
Wyniki. Wartość dietetyczna suplementowanych chrupek zależy od rodzaju i ilościowego udziału otrąb. Zawartość błonnika pokarmowego w wytworzonych próbkach wahała się od 6,47 do 15,72\%, w tym błonnika rozpuszczalnego od 2,06 do 3,70\%. Wraz ze wzrostem zawartości otrąb malała ekspansja, zwiększała się gęstość i zmieniała się barwa ekstrudatów (zmniejszenie jasności, zwiększenie wartości a*, zmniejszenie b*). W ocenie sensorycznej największą pożądalność uzyskały chrupki z 20-procentowym dodatkiem otrąb owsianych, a najmniejszą - z otrębami pszennymi w ilości 40\%. Na podstawie analizy PCA stwierdzono dodatnią korelację pomiędzy ogólną pożądalnością a chrupkością, porowatością, smakiem, barwą i wielkością ekspansji oraz ujemną pomiędzy pożądalnością a twardością i gęstością ekstrudatów. Zastosowane dodatki i ich wielkość wpływały także na zmianę lepkości wodnych zawiesin mierzonych w RVA. Nie stwierdzono jednak korelacji pomiędzy cechami jakościowymi ekstrudatów a wartościami wyróżników mierzonych w analizie lepkości.

Wnioski. Do produkcji kukurydzianych przekąsek ekstrudowanych, w zaproponowanych w pracy warunkach obróbki ciśnieniowo-termicznej, może być zalecany dodatek otrąb owsianych, pszennych i żytnich na poziomie $20 \%$. Produkty takie charakteryzowały się odpowiednią jakością sensoryczną i dietetyczną. Test lepkości w temperaturze kleikowania nie znalazł zastosowania w ocenie przydatności surowca kukurydzianego z dodatkiem otrąb owsianych, pszennych i żytnich do produkcji ekstrudatów.

Słowa kluczowe: ekstruzja, otręby, błonnik pokarmowy, test lepkości w temperaturze kleikowania, jakość

Received - Przyjęto: 27.05.2015

Accepted for print - Zaakceptowano do druku: 3.08.2015

For citation - Do cytowania

Makowska, A., Polcyn, A., Chudy, S., Michniewicz, J. (2015). Application of oat, wheat and rye bran to modify nutritional properties, physical and sensory characteristics of extruded corn snacks. Acta Sci. Pol. Technol. Aliment., 14(4), 375-386. DOI: 10.17306/J. AFS.2015.4.37 